\title{
THE PALAEONTOLOGICAL HERITAGE OF RIBEIRA DE CACELA (ALGARVE, PORTUGAL). ITS PRESERVATION IN THE PORTUGUESE CONTEXT
}

\author{
Ana SANTOS', Carlos MARQUES DA SILVA², \\ Tomasz BOSKI', Mário CACHÃO', \\ Luis CANCELA DA FONSECA ${ }^{3}$ and Delminda MOURA'

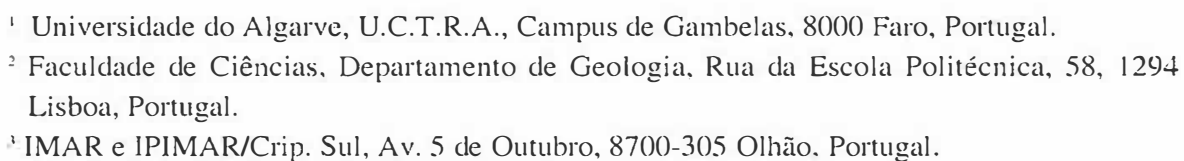

Santos, A., Marques Da Silva, C., Boski, T., Cachão, M., Cancela Da Fonseca, L. and Moura, D. 2001. The palaeontological heritage of Ribeira de Cacela (Algarve, Portugal). Its preservation in the Portuguese context. [El patrimonio paleontológico de Ribeira de Cacela (Algarve, Portugal). Su preservación en el contexto portugués.] Revista Española de Paleontología, no extraordinario, 99-103. ISSN 0213-6937.

\begin{abstract}
The protection of palaeontological heritage is justified by its own specificity, which results from its limited visibility, spatial variability, irreproducibility and importance as a record of past biodiversity. Until the present in Portugal the laws concerning the preservation of natural areas are focused mainly on the protection of threatened living species and their habitats, neglecting any geological aspect, and even less the concept of palcieontological heritage. The present analysis refers to the fossil-site of Ribeira de Cacela, included in the Natural Park of Ria Formosa (Algarve, southern Portugal), which represents a site of great paleontological interest. No particular palaeontological inventory being still available, and no any effective protective measures having yet been applied, the result is a continuous dilapidation of the palaeontological heritage, caused by sediment removal and, especially, by the continuous exploitation of sites by uncontrolled fossil collectors. The obvious consequence is the loss of important scientific information. Considering the palaeontological importance of this area, as well as its scientific, educational and cultural interest, a formal proposal will be made to the Instituto da Conservação da Natureza (the Portuguese Nature Conservation Institute), in order to nominate this outcrop as a Natural Monument and to promote its protection. Although the proposed legal protection is expected to be a long and difficult process, they will be rewarded by the resulting benefits.
\end{abstract}

Keywords: Palaeontological heritage, natural resources management, Ria Formosa Natural Park, Cacela, southern Portugal.

\section{RESUMEN}

La salvaguarda del patrimonio paleontológico se justifica por su propria especificidad, que resulta en gran medida de su carácter inmueble y limitación espacial, irreproducibilidad y por su importancia como testimonio insustituible de la diversidad biológica del pasado. Hasta el momento, en Portugal las leyes de conservación de los espacios naturales existentes se centran principalmente en la protección de las especies vivas amenazadas y de su entorno biotico, sin englobar aspectos geológicos y, mucho menos, el concepto de patrimonio paleontológico. El presente trabajo se refiere al yacimento de Ribeira de Cacela, localidad de gran valor paleontológico, incluido en el Parque Natural de Ria Formosa (Algarve, Portugal). La inexistencia de un inventario paleontológico formal y de medidas de protección efectivas, da lugar al deterioro continuo del patrimonio paleontológico, originado por remoción de sedimento y, especialmente, por el expolio de los fósiles. La consecuencia de estos hechos es la pérdida de información paleontológica, científica, educativa y cultural de esta área. Con el objetivo de promover la conservación de este yacimiento, se ha elevado una propuesta formal al Instituto da Conservação da Natureza (Instituto de la Conservación de la Naturaleza en Portugal), para su nominación como Monumento Natural. A pesar de que esta propuesta pasará por un proceso difícil y lento, estas 
dificultades se verán recompensadas por los beneficios resultantes de la protección y gestión del patrimonio paleontológico existente.

Palabras clave: Patrimonio paleontologico, gestión de recursos naturales, Parque Natural de la Ría Formosa, Cacela, sur de Portugal.

\section{PALAEONTOLOGICAL HERITAGE IN PORTUGAL}

The Portuguese palaeontological heritage has recently been the focus of a growing social concern, regarding its conservation as an important part of the different heritages that represent the basis of our cultural identity. Important contributions for this increasing interest have been some recent palaeontological findings, some of them of international significance, such as the Pedreira do Galinha dinosaur track site (Santos et al., 1994) and the Lourinhã Theropod embryos (Mateus et al., 1997).

The idea that the conservation of natural heritage constitutes a key-factor for a rational management of our society leads each of us to try to rejoin nature (Alcalá, 1993). However, in Portugal in spite of recent developments, this trend is focused mainly on living creatures, and does not include the geological substrate or its related history. So, due to the inexistence of a social concern towards their preservation, palaeontological sites are subjected to several aggressions, especially of anthropic nature, often resulting in irreparable loss of important palaeontological data.

The protection of the palaeontological heritage is justified by its own specificity, which results from its limited extension of sites, spatial variability and irreproducibility. Fossil outcrops from a certain geological time period do not constitute a renewable heritage resource, the need of an effective protection becomes evident, both in order to counter natural destructive fossildiagenetic processes, as to protected them from anthropical aggressions to which they are exposed (Alcalá, 1993).

In Portugal, concern about protection of natural resources only began to obtain some importance in the beginning of the 70's. In fact, at this time the concepts of Natural Park and Natural Reserve were introduced in the Portuguese legislation by the National Act Regulation $n^{\circ}$ $9 / 70$, of $19^{\text {th }}$ June 1970 . Since then, those concepts have evolved, and nowadays they are regulated by the National Act Regulation $n^{\circ} 19 / 93$, of $23^{\text {rd }}$ January 1993, in which are defined as follows:

- National Parks, Natural Parks, Natural Reserves and Natural Monuments, relative to the preservation of areas of national importance;

- Protected Landscapes, relative to the preservation of regional and local areas;

- Sites of Biological Interest, relative to the preservation of private areas.

So, the only portuguese laws concerning with the preservation of natural areas focus on the protection of threatened living species and their habitats, neglecting geological aspects, and obviously the concept of Palaeontological Heritage.
In Portugal, most of the palaeontological heritage is not protected by any legal regulation, and protected sites represent the exception instead of the general rule. Nevertheless the existence of a general legal framework, that would include aspects such as definition, protection and conservation of the portuguese palaeontological heritage, would be of extreme importance, because, as remarked by Morales and Azanza (1997) palaeontological heritage represents an irreplaceable testimony of the biological diversity of past times. The most paradoxical in Portugal is the Middle and Upper Jurassic of Cabo Mondego (near Figueira da Foz), where the first attempts of establishing its legal protection occurred more than twenty years ago. This although being formally defined and internationally recognised, has not yet been given any attention by the political authorities (Henriques, 1998) and is still seriously threatened by the local cement industry.

Yet, this situation might be changing soon, since scientific interest and social concern on fossil-sites is slowly growing among the palaeontological community and the general population. An example of this trend was the recent nomination by the Ministry of Science and Technology of Portugal, of the "Working Group for the Palaeontological Heritage". This group was created on the $19^{\text {th }}$ March 1999 and a final report was produced by July of this same year. Four recommendations were made: (1) to implement post-graduation courses on Paleontology; (2) to define an independent referee panel to evaluate scientific national projects on Paleontology; (3) to legislate on protection of the Palaeontological Heritage and ratify UNESCO resolutions and (4) to constitute a "National Council for the Palaeontological Heritage". Only recommendation 2 was achieved, so far.

\section{THE FOSSIL-SITE OF RIBEIRA DE CACELA}

The present analysis refers to the fossil-site of Ribeira de Cacela, included in the Natural Park of Ria Formosa (Algarve, Southern Portugal) (Fig. 1). From a geological point of view, the Ribeira de Cacela outcrop belongs to the cenozoic morphostrutural unit and it's included at the Cacela Formation (Ribeiro et al., 1979). Calcareous nannofossils from the classic Cacela fossiliferous outcrop (Lower Member) allowed to spot into the biozone NN 11 of Martin (1971 in Cachão, 1995) - CN 9a of Okada and Bukry (1980 in Cachão, 1995), chronostratigraphic equivalent to the Upper Tortonian (Cachão, 1995).

The Natural Park of Ria Formosa has a total area of $18.400 \mathrm{ha}$, distributed along approximately $60 \mathrm{~km}$ of coastline. This important natural area was given the status 


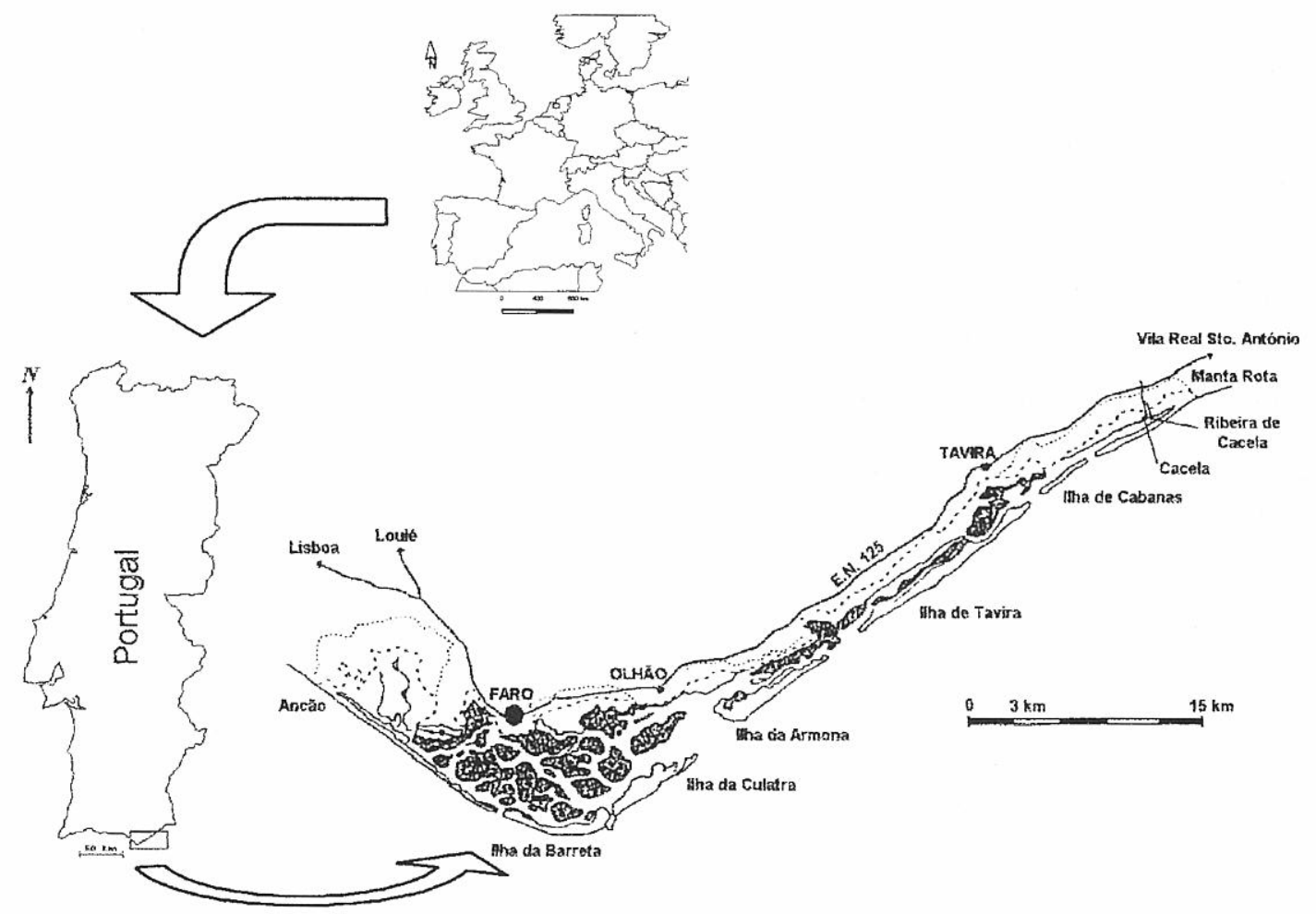

Figure 1. Geographic location of Ria Formosa Natural Park and the fossil-site of Ribeira de Cacela (Algarve, Portugal).

of Natural Reserve in 1978 (National Act Regulation $\mathrm{n}^{\circ} 45 / 78$, of $2^{\text {nd }}$ May) and in 1987 the status of Natural Park (National Act Regulation $n^{\circ} 373 / 87$, of $9^{\text {th }}$ December). The main reasons for its creation was mainly the protection and conservation of the Ria Formosa lagoon system, particularly its flora and fauna content, including their habitats. However, the important and abundant palaeontological heritage located in this area was not considered in its classification.

Despite the great palaeontological relevance of fossilsite in Ribeira de Cacela, a precise fossil and site inventory has not yet produced, and no effective protective measures have been applied yet. Nevertheless, this outcrop displays a privileged situation, in relation to most of the palaeontological sites, due to its inclusion in a protected area, such as a Natural Park. However this is still insufficient, since dilapidation of palaeontological heritage, due to sediment removal and, especially, to continuous destruction of fossils by private collector and fossil traders is not stopped. The obvious consequence is the loss of important scientific information.

Considered as a classic fossil-site, since a long time ago, the fossils included in the Ribeira de Cacela, have been the subjects of attention by several authors and publications. The interest for this fossil-site goes back to the mid-nineteenth century, with works by Pereira da Costa (1866-67) and Cotter (1879). Latter, many other works have been published on the same subject and among them the most important are Dollfus et al. (190304), Bourcart and Zbyszewski (1940), Chavan (1940), Zbyszewski and Almeida (1950), Ferreira (1951), Freneix (1957) and Brébion (1957). After a twenty-year interval, the study of this area was continued by Antunes et al. (1981), Pais (1982), Antunes and Pais (1992), Cachão and Silva (1992), Cachão (1995), Gonzales Delgado et al. (1995) and Santos (2000).

Some singular features that make Ribeira de Cacela a heritage to preserve are:

- Its historical value, since it was already known in the mid-nineteenth century.

- The wealth and diversity of the recorded fossilassociations, especially invertebrates. Among them, molluscs are especially abundant and bivalves are most common, including the Veneridae, Tellenidae, Cardiidae, Pectinidae and Lucinidae which are the families with the greatest number of species (Santos, 2000). Gastropods (Turritelidae, Naticidae and Conidae, among others) and scaphopods are also common (Cachão, 1995).

- The excellent preservation of fossils, particularly bivalves and gastropods; the existence of vestigial coloration in some, as well the preservation in life position of many specimens.

- The fact that it is the only portuguese outcrop representing the Upper Tortonian (Biozone CN 9a of Okada and Bukey (1980 in Cachão, 1995), circa 8.2 to 7.5 Ma of Cande and Kent (1992 in Cachão, 1995).

- The existence of fossils from this site in collections of numerous european museums, and its almost complete absence in portuguese collections; this absence was caused mainly by the big 1978 fire in the Portuguese Natural History Museum, which resulted in the loss of the majority of collections; 
there is also a lack of appropriate infrastructures (Geology and Palaeontology museums), where the management and the use of the enormous portuguese palaeontological potential could be made.

- Its importance for pedagogical (palaeo)environmental activities, as well as its importance for the local communities.

For all the above reasons, the Ribeira de Cacela outcrop is already considered as a reference in european palaeontology literature. Confirming this are the numerous articles were the Ribeira de Cacela outcrop is the subject such as Pereira da Costa (1866-67), Dollfus et al. (1903-04), Chavan (1940), Freneix (1957), Davoli (1976), González Delgado et al. (1995), among others.

\section{NEED OF PROTECTION}

The development of a formal inventory of this fossilsite should be an essential goal in order to obtain a complete information and increase social awareness of population on the palaeontological importance of this area, as well as to fully take advantage of its scientific, educational and cultural interest.

This inventory should be co-ordinated by the entity already responsible for the preservation and protection of the area where the outcrop is located - the Ria Formosa Natural Park. The Natural Park can only benefit from the enlargement of it activity, as it would be able to develop a new area of knowledge not explored so far. Also, only when we have a complete knowledge about the fossil content and others features of the site, will it be possible to propose and apply objective legal measures in order to assure an effective protection of palaeontological heritage.

For all these reasons, a formal proposal will be made to the Portuguese Nature Conservation Institute, in order to nominate this outcrop as Natural Monument. The same was done, for instance, for the fossil-site of Pedreira do Galinha, included within a Natural Park, which has already been given this particular legal status.

The importance of protecting and preserving the palaeontological heritage should be clearly underlined, in order to promote its protection from spoliation, vandalism and uncontrolled collecting by amateurs and fossil traders. This protection must be accompanied by simultaneous valorisation measures, allowing accessibility to authorised visitors, researchers and palaeontologists, as well as the development of special programmes on (palaeo)environmental education activities.

\section{CONCLUSIONS}

The inexistent of a legal status, specifically palaeontological, concerning Portuguese palaeontological heritage promote the existence of several aggressions, which often results in irreparable loss of important scientific data.
The protection of palaeontological heritage is justified by its own specificity, which results from its rarity as well as its singularity. Because palaeontological heritage represents the biogeological memory of the Planet and do not constitute a natural renewable heritage resource, the need of an effective protection becomes evident.

So, although legal protection measures on Ribeira de Cacela fossil-site might constitute a long and difficult process, the problems will be largely compensated by the resulting benefits, in terms of protection and management of the palaeontological heritage. Only through a timely application of these measures, it will be possible to guarantee the preservation of this natural heritage, as well as its transfer on to future generations.

\section{ACKNOWLEDGEMENTS}

The authors are grateful to the revisers Guillermo Mélendez and Celia Soria-Llop (University of Zaragoza), as well Maria Helena Henriques (University of Coimbra Portugal) for their useful comments and suggestions, and critical reading of the manuscript that have been most helpful for the improvement of the final version of this paper. We also thank Carolina Castillo Ruiz (University of La Laguna), who kindly provided suggestions in the spanish text.

\section{REFERENCES}

Alcalá, L. 1993. La conservación de los yacimientos paleontológicos europeos. EUROPAL. European Palaeontological Association, 4, 17-21.

Antunes, M.T. and Pais, J. 1992. The Neogene and Quaternary of Algarve. In: Atlantic General Events During Neogene, I Cong. RCANS, Ciências da Terra (U.N.L.), no esp. 2, 57-66.

Antunes, M.T., Bizon, G., Nascimento, A. et Pais, J. 1981. Nouvelles donnés sur la datation des dépôts miocènes de l'Álgarve (Portugal), et l'évolution géologique regional. Ciências da Terra (U.N.L.), Lisboa, 6, 153-168.

Bourcart, J. et Zbyszewski, G. 1949. La faune de Cacela en Algarve (Portugal). Comunicações dos Serviços Geológicos de Portugal, Lisboa, 11, 3-60.

Brébion, Ph. 1957. Le Mitra fusiformis des couches tortoniennes de Cacela est une espéce nouvelle: Mitra pereirai n. sp. Comunicações dos Serviços Geológicos de Portugal, Lisboa, 38(1), 241-242.

Cachão, M. 1995. Utilização de Nanofósseis calcários em biostratigrafia, paleoceanografia e paleoecologia. Aplicações ao Neogénico do Algarve (Portugal) e do Mediterrâneo Ocidental (ODP 653) e à problemática do Coccolithus pelagicus. Ph.D. dissertation, Faculdade de Ciências da Universidade de Lisboa, Lisboa, 356 pp, (unpublished).

Cachão, M. and Silva, C.M. 1992. Neogene palaeogeographic evolution of Algarve Basin (Southern Portugal): a two step model. Preliminary data. Gaia, 4, 39-42. 
Chavan, A. 1940. Les fossiles du Miocène supérieur de Cacela. Comunicações dos Serviços Geológicos de Portugal, Lisboa, 21, 61-106.

Cotter, J.C.B. 1879. Fósseis das bacias Terciárias marinhas do Tejo, do Sado e do Algarve. Jornal de Sciencias Mathematicas, Physicas e Naturaes, Lisboa, 7(26), 112122.

Davoli, F. 1976. Terebridae (Gastropoda: Taxoglossa) come probabili validi documenti per l'interpretazione paleoecologica e geologico-storica di bacini neogénice europei. Bolletino della Società Paleontologica Italiana, 15 (1), 49-58.

Dollfus, G.F., Cotter, J.C. et Gomes, J.P. 1903-04. Mollusques Tertiaires du Portugal. Planches de Cephalopodes, Gastéropodes et Pélècypodes laissés par F. A. Pereira da Costa. Comunicações dos Serviços Geológicos de Portugal, Lisboa, 34, 46 pp.

Ferreira, O.V. 1951. Os Pectinídeos do Miocénico do Algarve. Comunicações dos Serviços Geológicos de Portugal, Lisboa, 32(1), 153-173.

Freneix, S. 1957. Lamellibranches nouveaux du Miocéne du Portugal. Comunicações dos Serviços Geológicos de Portugal, Lisboa, 38(1), 227-239.

Gonzales Delgado, J., Andres, I. and Sierro, J. 1995. Late Neogene molluscan faunas from the Northeast Atlantic (Portugal, Spain, Marocco). Geobios, 28, 459-471.

Henriques, M.H. 1998. O Jurássico do Cabo Mondego e a projecção internacional do património geológico português. I Encontro Internacional sobre Paleobiologia dos Dinossáurios. Programa de Musealização para pistas de Dinossáurios em Portugal. Museu Nacional de História Natural, Lisboa, 98-103.

Mateus, I., Mateus, H., Antunes, M.T., Mateus, O., Taquet, Ph., Ribeiro, V. et Manuppella, G. 1997. Couvée, oeufs et embryons d'un Dinosaure Théropode du Jurassique supérieur de Lourinhã (Portugal). Compte Rendus de l'Academie des Sciences de Paris, 71-78.

Morales, J. y Azanza, B. 1997. Los parques paleontológicos, una alternativa de gestión para recursos paleontológicos de alto potencial didáctico, cultural y artístico. Comunicaciones de la III Reunión de la Comisión de Patrimonio Geológico (Eds. L. Pallí y J. Carreras), Girona, 51-54.

Pais, J. 1982. O Miocénico do Litoral Sul Português. Ensayo de sintese. Trabalho complementar para obtenção do grau de Doutor, Universidade Nova de Lisboa, 47 pp. (unpublished).

Pereira da Costa. 1866-67. Molluscos fósseis, Gasteropodes dos depósitos terciários de Portugal. Memória da Comissão Geológica de Portugal, Lisboa, 4, $1^{\circ}$ caderno: 1-116, est. I-XV, (1866); $2^{\circ}$ caderno: $117-252$, est. XVIXXVIII, (1867).

Ribeiro, A., Antunes, M.T., Ferreira, M., Rocha, R., Soares, A., Zbyszewski, G., Almeida, F., Carvalho, D. et Monteiro, J. 1979. Introduction à la géologie générale du Portugal. Serviços Geológicos de Portugal, Lisboa, 114 pp.

Santos, A. 2000. Bivalves Marinhos do Miocénico superior (Tortoniano superior) de Cacela (Algarve, Portugal). Msc. Dissertation, Universidade do Algarve, Faro, 197 pp., (unpublished).

Santos, V.F., Lockley, M.G., Meyer, C.A, Carvalho, J., Galopim de Carvalho, A.M. and Moratalla, J.J. 1994. A new sauropod tracksite from the Middle Jurassic of Portugal. Gaia, 10, 5-14.

Zbyszewski, G. e Almeida, F.M. 1950. Os peixes miocénicos portugueses. Comunicações dos Serviços Geológicos de Portugal, Lisboa, 31, 309-412.

Manuscrito recibido: 5 de noviembre, 1999 Manuscrito aceptado: 12 de junio, 2000 